\title{
Biosynthesis of Silver Nanoparticles Using Bacteria Isolates from Wastewater
}

Shima Kazemi (MSc)

Department of Microbiology, Falavarjan Branch, Islamic Azad University, Falavarjan, Isfahan, Iran

Monir Doudi (MSc)

Department of Microbiology, Falavarjan Branch, Islamic Azad University, Isfahan, Iran

Gholm Reza Amiri (MSc) Department of Biology, Falavarjan Branch, Islamic Azad University, Isfahan, Iran

Corresponding author: Monir Doudi

Tel: $+983133220134-5$

E-mail: Doudi@iaufala.ac.ir

Address: Daneshgahboulevar, KamarbandiStreet, Falavarjan, Isfahan.

Received : 29 Jun 2016

Revised: 02 Jul 2016

Accepted: 26 Sep 2016
ABSTRACT

Background and Objectives: Development of ecofriendly processes for the synthesis of metal nanoparticles is of great importance in the field of nanotechnology. Microorganisms such as bacteria could be suitable candidates for bioproduction of nanoparticles due to their simplicity and high compatibility with the environment. The aim of this study was to use bacteria isolates from the effluent of wastewater treatment plants to produce silver nanoparticles.

Methods: For identifying silver-resistant microorganisms, we used the agar diffusion method using PHG II medium containing $0.5 \mathrm{mV}$ silver to determine minimum inhibitory concentration. Bacterial identification was done with biochemical testing and polymerase chain reaction (colony PCR). Finally, silver nanoparticles were produced in the desired bacteria, and the properties of these nanoparticles were studied.

Results: We found five silver-resistant bacteria among which Stenotrophomonas maltophilia strain MS8 showed the highest resistance (MIC $=6 \mathrm{mM})$. The bacterium was able to synthesize silver nanoparticles in spherical shapes. The results obtained from visual observations using IV-VIS, TEM and XRD showed that the bacterium was able to reduce silver ions into silver nanoparticles with maximum size of $20 \mathrm{~nm}$.

Conclusion: Based on our findings, this bacterium could be useful for biosynthesis of silver nanoparticles.

KEYWORDS: Bacteria, Biosynthesis, Minimum Inhibitory Concentration. 


\section{INTRODUCTION}

Synthesis of nanoparticles is a green and nontoxic method that has recently received a lot of attention. Various microorganisms feed on organic and mineral resources present in the environment for metabolism and vital processes. During these processes, exposure to metal ions lead to accumulation of the metal ions within or on their cell wall of these microorganisms, which mainly results in production of nanoscale particles (1). Although heavy metals are essential micronutrients for many microorganisms, they are harmful and toxic to humans in high concentrations. Therefore, it is necessary to remove heavy metals present in effluents before discharging them into water systems to avoid human health consequences (2). Biosorption of heavy metals is an effective and important technique employed for separation of heavy metals from industrial effluents and natural water resources (3). According to studies conducted on physiology and genetics of bacteria, there are four main mechanisms for protection of biological systems against these metal contaminants:

\section{Efflux systems (outward diffusion)}

This mechanism transfers toxic metal ions out of the cell (4). This mechanism may be ATPase-dependent or -independent, but it is specific for a particular heavy metal ion (5). Ptype ATPases have a main role in this type of resistance to heavy metals, and are a large family of membrane proteins that perform active ion transport across biological membranes (6).

\section{Accumulation and complex}

Due to the presence of metallothioneins and cysteine-rich proteins, this mechanism prevents exposure of essential cellular components to contaminants (4).

\section{Reduction}

Upon entry to the cell, toxic metal ions are enzymatically reduced and then exported from the cell into the environment (7).

\section{Altering the cellular components}

Some microorganisms may adapt to the presence of heavy metals through mutations that decrease the sensitivity to metal contaminants but maintain the cellular function by increasing the production of metalsensitive products (8).

Synthesis of nanoparticles by bacteria has the following advantages: 1 . It is easier to examine production of nanoparticles by bacteria, 2 . It is easier to cause genetic changes in bacteria compared with eukaryotic cells, 3. Bacterial system is more stable compared to the plant extracts, 4 . It is easier to work with bacteria on industrial and mass scale, 5. It is easier to assess molecular and cellular mechanism of nanoparticle formation in bacterial cells, 6 . It is easier to optimize conditions for production of nanoparticles with a particular shape and size in a bacterial system (9).

The aim of this study was to use bacteria isolates from the effluent of wastewater treatment plants to produce silver nanoparticles.

\section{MATERIAL AND METHODS}

All media used in this study including nutrient agar, nutrient broth, Mueller-Hinton agar, metal base PHG II agar, metal II PHG broth and silver nitrate $\mathrm{Ag}\left(\mathrm{NO}_{3}\right)$ were purchased from Scharlu Co., Spain. Polymerase chain reaction (PCR) buffer, Taq DNA polymerase, $50 \mathrm{mM} \mathrm{MgCl}, 10 \mathrm{mM}$ dNTPmix, distilled water, primers, green dye, agarose powder, DNA ladder, loading dye and TBE buffer (1X) were purchased from Sinagene Co., Iran.

Sampling was done from the effluent of two silver wastewater treatment plants in Isfahan. The temperature, $\mathrm{pH}$ and amount of biochemical oxygen demand (BOD), chemical oxygen demand (COD) and electrical conductivity (EC) of the effluent samples were measured. The number of heterotrophic bacteria present in each sample was calculated using the pour plate method with three replications. First, a series of dilutions was prepared from the samples and later cultured on nutrient agar using the pour plate method. Based on morphology of colonies grown on the medium, the desired colonies were selected and cultured in the PHGII medium containing $0.5 \mathrm{mM}$ silver. Then, minimum inhibitory concentration (MIC) of isolates resistant to heavy metals was determined using the agar dilution method (10).

A metallic solution at an appropriate concentration was added to the culture medium. Then, resistant colonies were cultured on the surface of a plate (11). Biochemical testing and colony PCR were performed after Gram staining for identification of the resistant bacteria. The isolates were cultured in PHG II broth and 
placed on a shaking incubator at $30{ }^{\circ} \mathrm{C}$ for 24 hours. The bacterial cultures were centrifuged at 2,500 rpm for 5 minutes, and the pellet was rinsed with deionized distilled water three times. One gram of the bacterial cells was added to an Erlenmeyer flask containing $25 \mathrm{ml}$ of $1 \mathrm{mM}$ silver nitrate solution. The flask was placed on a shaking incubator at $30{ }^{\circ} \mathrm{C}$ until a brown solution was obtained. After assessing qualitative changes in the sample, a small of amount of the resulting liquid was used to evaluate absorption spectrum using a UV-VIS spectrophotometer. The remaining deposits (the biomass of the desired bacterium) were dried by lyophilization. Finally, morphological and physicochemical properties of the samples were evaluated by X-ray diffraction (XRD) and transmission electron microscopy (TEM).

\section{RESULTS}

Table 1 shows the physicochemical properties of the effluents studied. The sample from treatment plant 2 (S2) had higher temperature and $\mathrm{BOD}, \mathrm{COD}$ and $\mathrm{EC}$ values compared to the sample from treatment plant 1 (S1). In addition, S2 had a lower $\mathrm{pH}$ (close to neutral) and amount of silver compared to $\mathrm{S} 1$.

Mean number of heterotrophic bacteria in S2 $\left(153.5 \times 10^{4} \mathrm{CFU} / \mathrm{ml}\right)$ was greater than that in $\mathrm{S} 1\left(55.6 \times 10^{4} \mathrm{CFU} / \mathrm{ml}\right)$, but the mean number of silver-resistant heterotrophic bacteria in $\mathrm{S} 1$ $\left(5.297 \times 10^{4} \mathrm{CFU} / \mathrm{ml}\right)$ was greater than that in $\mathrm{S} 2\left(2.187 \times 10^{4} \mathrm{CFU} / \mathrm{ml}\right)$. This could be due to the higher concentration of silver present in $\mathrm{S} 1$. We detected five silver-resistant isolates. Table 2 represents the MIC and minimum bactericidal concentration (MBC) values of the isolates detected. The results obtained from blast and phylogenetic tree of isolate $\operatorname{Ag} 6$ revealed that the strain was closely related (99\% similarity) to the bacterium Stenotrophomonas maltophilia R551-3. Therefore, the bacterium was registered in the GenBank (NCBI) as a new strain called $S$. maltophilia MS8 with the access number KP742984.

Table 1 -Physicochemical properties of the effluents collected from the silver treatment plants

\begin{tabular}{|c|c|c|c|c|c|c|}
\hline Effluents & $\begin{array}{l}\mathrm{BOD}_{5} \\
(\mathrm{mg} / \mathrm{l})\end{array}$ & $\mathrm{COD}(\mathrm{mg} / \mathrm{l})$ & $\mathrm{PH}$ & Temperature $\left(\mathrm{C}^{\circ}\right)$ & $\mathrm{EC}\left(\frac{d s}{m}\right)$ & $\mathrm{Ag}(\mathrm{ppm})$ \\
\hline $\begin{array}{l}\text { Sample from effluent } \\
\text { of silver treatment } \\
\text { plant } 1 \text { (S1) }\end{array}$ & 5 & 10 & 8.15 & 15 & 509 & 3.53 \\
\hline $\begin{array}{l}\text { Sample from effluent } \\
\text { of silver treatment } \\
\text { plant } 2 \text { (S2) }\end{array}$ & 72 & 184 & 6.79 & 17.2 & 655 & 0.893 \\
\hline
\end{tabular}

Table 2- The MIC and MBC values of silver-resistant bacteria

\begin{tabular}{|c|c|c|c|c|c|c|c|c|c|c|c|c|c|c|c|c|c|c|c|c|}
\hline \multirow[t]{2}{*}{ Isolate } & \multicolumn{18}{|c|}{ Concentration of silver (mM) } & \multirow[t]{2}{*}{$\mathrm{MIC}(\mu \mathrm{g} / \mathrm{ml})$} & \multirow{2}{*}{$\begin{array}{c}\text { MBC } \\
(\mu \mathrm{g} / \mathrm{ml})\end{array}$} \\
\hline & 0.5 & 1 & 1.25 & 1.5 & 1.75 & 2 & 2.5 & 3 & 3.5 & 4 & 4.5 & 5 & 5.5 & 6 & 6.5 & 7 & 7.5 & 8 & & \\
\hline $\mathbf{A g}_{1}$ & + & + & - & - & - & - & - & - & - & - & - & - & - & - & - & - & - & - & 2 & 3 \\
\hline $\mathbf{A g}_{2.5}$ & + & + & + & + & + & + & + & - & - & - & - & - & - & - & - & - & - & - & 3.5 & 4.5 \\
\hline $\mathbf{A g}_{3}$ & + & + & + & + & + & + & + & + & - & - & - & - & - & - & - & - & - & - & 4 & 5 \\
\hline $\mathbf{A g}_{5}$ & + & + & + & + & + & + & + & + & + & + & - & - & - & - & - & - & - & - & 5 & 6 \\
\hline $\mathbf{A g}_{6}$ & + & + & + & + & + & + & + & + & + & + & + & + & - & - & - & - & - & - & 6 & 7 \\
\hline
\end{tabular}

Figure 1- The phylogenetic tree obtained from isolate Ag6

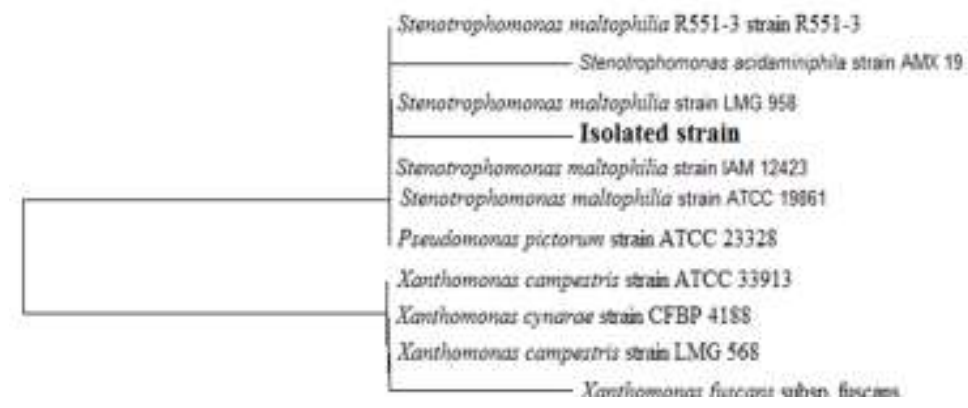


45/ Kazemi and colleagues

Table 3- Molecular and microscopic identification of the five silver-resistant bacteria

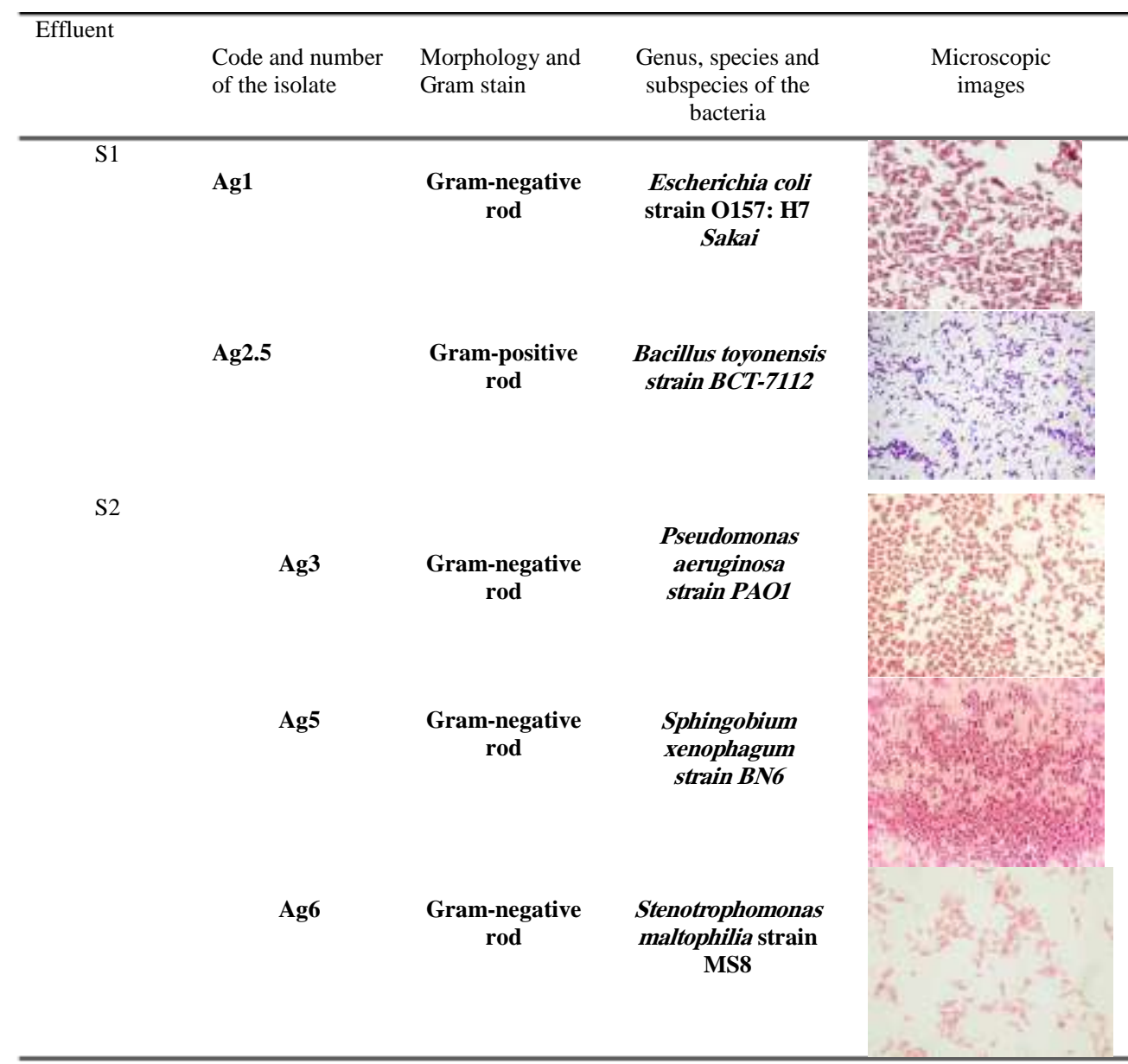

Among the five resistant isolates, $S$. maltophilia MS8 (MIC $=6 \mu \mathrm{g} / \mathrm{ml})$ was able to turn the colorless stock solution of silver nitrate (containing $0.4246 \mathrm{~g}$ of silver nitrate in $25 \mathrm{ml}$ of deionized distilled water) into a dark- brown solution. Therefore, the isolate was selected for further processing. UV-VIS absorption spectrum of $S$. maltophilia MS8 reached its peak at $345 \mathrm{~nm}$ in the presence of 1 $\mathrm{mM}$ silver nitrate at $500{ }^{\circ} \mathrm{C}$ (Figure 2).

Figure 2- The UV-VIS absorption spectrum of $S$. maltophilia MS8

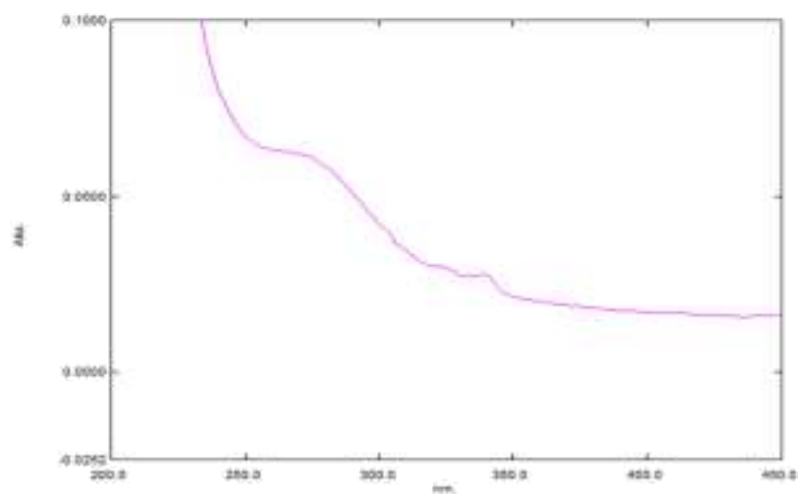


Figure 3- The XRD graph for the silver nanoparticles produced at $500{ }^{\circ} \mathrm{C}$

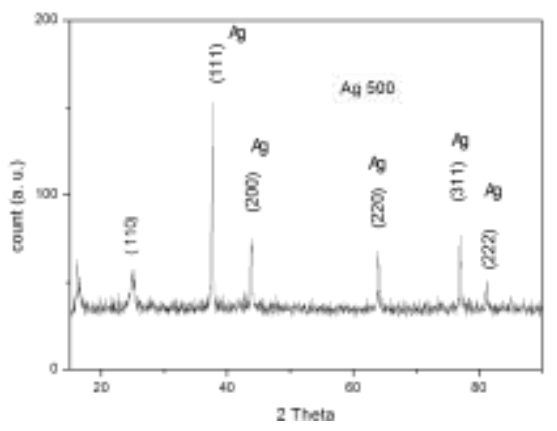

\section{DISCUSSION}

Bacteria and all other microorganisms are influenced by environmental factors. In our study, $\mathrm{pH}$ of S1 and S2 was alkaline and acidic (close to neutral), respectively. The desirable $\mathrm{pH}$ for most bacteria is neutral, and changes in the $\mathrm{pH}$ of an environment will affect the microbial population of that environment (12). As expected, we observed a decline in the population of heterotrophic bacteria in S1. This finding is consistent with the study of Albughbish et al. (13). The mentioned study stated that the population of heterotrophic bacteria increases significantly in neutral $\mathrm{pH}$ compared to acidic and alkaline conditions. In this study, we found no relationship between the increased EC and the population of bacteria, which is similar to the results of a study by Tahmourespour et al. (14). Similar to our study, Hussein et al. observed that elevated BOD and COD would increase the population of heterotrophic bacteria (15). However, a study by Azadany has shown the opposite (16).

We also found that presence of toxic concentrations of silver reduced the number of bacteria. Several studies have shown the notable effects of heavy metals on microbial population. On the other hand, microorganisms resistant to these pollutants are able to tolerate metal toxicity (17).

Similar to our study, Nangia et al. managed to produce gold nanoparticles using a new strain of $S$. maltophilia, which was isolated from a gold mining area (18). Some previous studies have used different concentrations of silver nitrate solution to produce silver nanoparticles using E. coli and P. aeruginosa $(19,20)$. In the present study, after determining the MIC, we used $1 \mathrm{mM}$ of silver nitrate for the production of nanoparticles. In 2016, Ahmad et al. used
Azadirachta indica soluble extract for the synthesis of silver nanoparticles (21).

In the UV-VIS graph, we found a specific absorption peak at $345 \mathrm{~nm}$ and another peak at $278 \mathrm{~nm}$. Narasimha et al. observed an absorption peak at $280 \mathrm{~nm}$ and reported that this may be due to the presence of the amino acids (tryptophan and tyrosine) remaining in the bacteria, which were fixed along with silver nanoparticles (22). The presence of silver nanoparticles could be assessed by reading optical density at a wavelength between 300 and $500 \mathrm{~nm}$ using a UV-VIS spectrophotometer. In this method, a peak at $345 \mathrm{~nm}$ would verify the presence of silver nanoparticles (23).

In our study, the results obtained from XRD at $111,200,220,311$ and 222 were consistent with the reference card of silver nanocrystals (JCPDS 04-0783) (24). However, only at angle of $24.8^{\circ}$, the result of XRD was similar to the reference card of $\mathrm{Ag}_{2} \mathrm{O}$ (JCPDS 76-1393) (25). The images obtained from TEM showed that the silver bio-nanoparticles produced in our study have spherical shape and diameter of 20 nm. Zaki et al. observed that E. coli (S30, S78), B. megaterium (S52), Acinetobacter spp. (S7) and S. maltophilia (S54) are potential candidates for synthesis of silver nanoparticles (26), which is in agreement with our findings. Saifuddin et al. used B. subtilis to produce silver nanoparticles with diameter of 5-60 nm (27). Ashengroph et al. also produced silver nanoparticles in size of 5-20 nm using Ralstonia (28). Since smaller particles have a larger surface area to volume ratio, which would increase the particles efficiency, it can be concluded that the nanoparticles produced in our study may have high performance in nanotechnology. 


\section{CONCLUSION}

Our findings indicate that the bacteria isolates from effluent of silver treatment plants could be useful for the biological removal of the heavy metal such as silver. Moreover, these microorganisms could be used for biological production of silver nanoparticles.

\section{REFERENCES}

1. Thakkar KN, Mhatre SS, Parikh RY. Biological synthesis of metallic nanoparticles. NBM. 2010; 6(2): 257-262. doi: 10.1016/j.nano.2009.07.002.

2. Fillali Bk, Taoufik J, Dzairi FZ, Talbi M, Blaghen M. Waste water bacterial isolates resistant to heavy metals and antibiotics. Current Microbiology. 2000; 41(3): 151-156.

3. Veglio F, Esposito A, Reverberi AP. Standardization of heavy metal biosorption test. Process Biochemistry. 2003; 38(6): 953-961.

4. Bruins MR, Kapil S, Oehme FW. Microbial resistance to metals in the environment. Ecotoxicology and Environmental Safety. 2000; 45(3): 198-207.

5. Nies DH, Silver S. Ion efflux systems involved in bacterial metal resistance. Journal of Industrial Microbiology. 1995; 14(2): 189-199. 6. Apell HJ. Structure-function relationship in P-type ATPases- a biophysical approach. Reviews in Physiology, Biochemistry and Pharmacology. 2003; 150: 135.

7. Nies DH. Microbial heavy metal resistance. Applied Microbiology and Biotechnology. 1999; 51(6): 730-750.

8. Rouch DA, Lee BT, Morby AP. Understanding cellular responses to toxic agents: a model for mechanism-choice in bacterial metal resistance. Journal of Industrial Microbiology. 1995; 14(2): 132-141.

9. Kalishwaralal K, Deepak V, Ram Kumar Pandian S, Kottaisamy M, BarathManikanth S, Kortikeyan B, et al. Biosynthesis of silver and gold nanoparticles using Brvibacteriumcasei. Colloids and Surfaces B. Biointerfaces. 2010; 77(2): 257-262. doi: 10.1016/j.colsurfb.2010.02.007.

10. Andrews JM. Determination of minimum inhibitory concentration. Journal of Antimicrobial Chemotherapy. 2001; 48(suppl 1): 5-16.

11. Hassen A, Saidi N, Cherif M. Resistance of environmental bacteria to heavy metals. Bioresource Technology. 1998; 64(1): 7-15.

12. Jawetz A, Melnick g, Adelbergs A. Medical microbiology. $26^{\text {th }}$ ed. Iran. Sana. 2016; 428.

13. Alboghobeysh H, Tahmourespour A, Doudi M. Antibiotic resistance in isolated bacteria from urban sewage and copper smeltery industrial wastewater. Journal of Gorgan University of Medical Sciences. 2013; 15(1): 95102.

14. Tahmourespour A, Kasra Kermanshahi R, Noohi A. The relationship between physicochemical wastewater with resistant bacteria. Journal of Environmental Science and Technology. 2005; 24: 43-54.

15. Hussein H, Farag IS, Kandeel K, Moawad H. Biosorption of heavy metals from wastewater using Pseudomonas sp. Environmental Biotechnology. 2004; 7(1): 1-7.

16. Nasrazadany A, Hoodaji M, Tahmourespour A, kabirinejad SH. The relationship between the characteristics of industrial effluents with heavy metal resistant bacteria for

\section{ACKNOWLEDGMENTS}

The authors would like to thank all those who helped us throughout this study, particularly the staff of Azad University of Falavarjan for providing the research facilities.

\section{CONFLICT OF INTEREST}

The authors have no conflict of

biological treatment. The Third National Congress of Recycling and Using Renewable Organic Resources in Agriculture. Khorasgan, Islamic Azad University Khorasgan Branch. 2008; 1-7.

17. Maier RM, PapperIL, Gebra CP. Environmental Microbiology. Academic Press Chapter. 2000; 17: 403-423.

18. Nangia Y, Wangoo N, Goyal N, Shekhawat G, Suri CR. A novel bacterial isolate Stenotrophomonas maltophilia as living factory for synthesis of gold nanoparticles. Microbial Cell Factories. 2009; 8:39. doi: 10.1186/1475-2859-8-39.

19. Vaidyanathan $\mathrm{R}$, kalishwarala K, Gopalram SH, Gurunathan S. Nano silver-The burgeoning therapeutic molecule and its green synthesis. Biotechnology Advances. 2009; 27(6): 924-937. doi: 10.1016/j.biotechadv.2009.08.001.

20. Jeevan P, Ramya K, Edith Rena A. Extracellular biosynthesis of silver nanoparticles by culture supernatant of Pseudomonas aeruginosa. Indian Journal of Biotechnology. 2012; 11:72-76.

21. Ahmed SH, Ahmad M, Swami BL, Ikram S. Green synthesis of silver nanoparticles using Azadirachta indica aqueous leaf extract. Journal of Radiation Research and Applied Sciences. 2016; 9(1): 1-7.

22. Narasimha G, Praveen B, Mallikarjuna K, Deva Prasad Raju B. Mushrooms (Agaricusbisporus) mediated biosynthesis of sliver nanoparticles, characterization and their antimicrobial activity. International Journal of Nano Dimension. 2011; 2(1): 29-36. DOI: 10.7508/ijnd.2011.01.004.

23. Cathrine R, Ragunathan R, Prasanna Kumar K. Biosynthesis of silver nanoparticles using L. Acidophilus (probiotic bacteria) and its application. International Journal of Nanotechnology and Applications. 2010; 4(3): 217-222.

24. Park HH, Zhang X, Choi YJ, Park HH, Hill RH. Synthesis of Ag nanostructures by photochemical Reduction using citrate-capped pt seeds. Journal of Nanomaterials. 2011: 1-7.

25. Dhoondia ZH, Chakraborty H. Lactobacillus Mediated Synthesis of Silver Oxide Nanoparticles. Nanomaterials and Nanotechnology. 2012; 2(1): 1-7.

26. Zaki S, El Kady MF, Abd-El-Haleem D. Biosynthesis and structural characterization of silver nanoparticles from bacterial isolates. Materials Research Bulletin. 2011; 46(10): 1571-1576.

27. Saifuddin N, Wong CW, Nuryasumira AA. Rapid biosynthesis of silver nanoparticles using culture supernatant of bacteria with microwave irradiation. E.Journal of Chemistry. 2009; 6(1): 61-70.

28. Ashengroph M. Extracellular synthesis of silver nanoparticles by Ralstonia sp.SM8 isolated from the sarchemeh copper mine. Biological Journal of Microorganism. 2014; 3(9): 53-64. 